\title{
ECOLOGICAL AND ENVIRONMENTAL RISK ASSESSMENT IN THE NANOMATERIALS PRODUCTION
}

\author{
TORABIFARD, M. ${ }^{1}$ - ARJMANDI, R..$^{1 *}$ - RASHIDI, A. M. ${ }^{2}-$ NOURI, J. ${ }^{1}-$ MOHAMMADFAM, I. ${ }^{3}$ \\ ${ }^{I}$ Department of Environmental Management, Faculty of the Environment and Energy, Science \\ and Research Branch, Islamic Azad University, Tehran, Iran \\ e-mail:torabifard.mina@yahoo.com; r.arjmandi90@gmail.com; nourijafar@gmail.com \\ ${ }^{2}$ Nanotechnology Research Center, Research Institute of Petroleum Industry, Tehran, Iran \\ e-mail: rashidiam@gmail.com \\ ${ }^{3}$ Department of Occupational Health and Safety, Faculty of Health, University of Medical \\ Science, Hamedan, Iran \\ e-mail:Iraj_f@yahoo.com \\ *Corresponding author \\ e-mail: r.arjmandi90@gmail.com, tel: +98-21-44845144,fax: +98-21-44869442
}

(Received $19^{\text {th }}$ Mar 2017; accepted $1^{\text {st }}$ Aug 2017)

\begin{abstract}
In this study, the spray pyrolysis and hydrothermal production processes of nanostructured zinc oxide were compared in terms of health and environmental risk on a semi-industrial scale with a capacity of $2000 \mathrm{~kg} /$ year. For this, environmental release and human exposure to identified sources of pollution in each production process were modeled using the Chemical Screening Tool for Exposure and Environmental Release (ChemSTEER) software. Spray pyrolysis and hydrothermal were compared pairwisely by analytic hierarchy process (AHP), which is a multi-criteria decision-making model using health and environmental indicators. According to AHP results and box plot chart, hydrothermal process leads to a higher health and environmental median inverse risk compared with spray pyrolysis. Thus the synthesis of nanostructured zinc oxide by hydrothermal process is safer than spray pyrolysis. Due to the growing development of the various methods of the nanomaterials, we need to apply the safer methods and to have the least ecological risks in the production of the nanomaterials. These findings could be helpful for modifying the operation and reducing the ecological potential risks to scale up the existing pilot plant to an industrial unit.
\end{abstract}

Keywords: ecological aspects, environmental release, nanotechnology, process design, analytic hierarchy process

\section{Introduction}

\section{Environment and ecological risk assessment}

The word "Ecology" literally means the mutual effects of the environment on the living organisms, and the living organisms on the environments along with interrelationships between organisms. (Michener, 2006) A branch of the ecology is to understand the relationship between man and the environment and their consequences on the environment. The experts have hardly emphasized on the effect of the human activities on the features of the ecosystem up to now. However, to figure out the structural changes in the ecosystem, we need to have a comprehensive understanding of the stressors and their impacts on the environment and the ecosystem. (Jounston et al., 2015) It should be noted that the chemical pollution is one of the stressors that we can find everywhere, and it can make some changes in the process of the ecosystem. (Mc Mahon et al., 2012). Pollutions from many sources in various formats can go to the 
ecosystem, besides they can cause many environmental risks. Therefore, the environmental risk assessment of the chemical contamination can be a step towards a reduction of the dangers and the protection of the environment. The risk assessment is a rational way to determine the size of the quantitative and qualitative hazards, and the possible consequences of the hazards on people, materials, equipment and the environment (ISO/IEC, 1998). It has four stages.

- The description and identification of the hazards.

- The exposure assessment (e.g. the emission or environmental fate).

- The risk assessment.

- The risk management (Ostertag and Husing, 2008). The results of the risk assessment can effectively lead to changes in the environmental management policies. (Vall-llosera and Sol, 2009). We consider the nanotechnology as an applicable technology in recent decades. This technology comes from the convergence of physics, chemistry and biology.

Some studies consider nanotechnology the next industrial revolution (Scrinis and Miller, 2006), as it is changing other industries, including health, environment, agriculture, energy, materials, and communication sciences (Rickerbya and Morrison, 2007).

Nanotechnology has been able to make some significant changes in various industries, for instance, using carbon nanotubes which have been able to upgrade the mechanical properties of tires, or the nanoparticles are used as the catalysts for the petrochemical industry. Nevertheless, the particles have the potential to cause the ecological hazards. Moreover, several factors can make the nanoparticles go to the environment through the air, soil and groundwater. They can be a threat to the organisms in the environment or vicinity of the environment. The key aspects of the risk assessment in the field of the nanomaterials are the identification of the physical and chemical properties of nanomaterials, the identification of the environmental hazards, the identification of the hazards, and how humans face with ecosystem risks and their effects (Colvin, 2003; Maynard, 2006). The results of the risk assessment are the important components to ensure various industries in the safety of their industry (Drobne, 2007). In this way, we can determine the efficiency of the inventory controlling procedures; moreover, we can prepare some valuable data for making decision on the reduction of the risks, hazards, upgrading the control systems and planning to respond to them.

\section{Ecological impact and nano technology}

Nanotechnology provides the ability to fabricate smaller materials with a significantly reduced volume of active materials, a high surface area to volume ratio, and increased performance (Moore, 2006; Gregory, 2010).

The high-level reactivity of the nanomaterials can be a threat to humans and the environment. This increased reactivity gets the nanoparticles to have an uncontrollable and unpredictable high potential in the reaction with many molecules found in the nature, cells and organisms. On the other hand, the very small size of the nanoparticles reinforces the hypothesis that particles can pass through the immune system. Some inhaled particles can enter the lungs; consequently, they can enter the bloodstream. (Moghimi and Hunter, 2001)

Due to the increasing consumption of these materials industries, for instance, the nanoparticles such as titanium dioxide are some of the air pollutants which can cause 
inflammation and lesions of the mucous, and accumulate in the lungs (Moghimi and Hunter, 2001). In addition, the nanoparticles of the titanium dioxide and zinc oxide in sunscreens can cause free radicals in skin cells and damage DNA. Damaging to DNA can also make some changes in the structure of the proteins and their functions; subsequently, they can lead to the cell cancer, the metastasis and tumors (Poirier, 2004). Titanium dioxide nanoparticles have some other applications including cleaning the environment, soil, water and air. Hence, these particles can easily enter the environment, and they can enter to the food chain through vegetarian and fish, owing to it, they can spread out in organisms in ecosystem. The processed carbon nanoparticles gluten causes the depletion and the oxidation in fish's brains and changes in the functions of genes. The substance can also be transmitted through the soil, as a result of it, earthworms can absorb these substances, and then they enter to the food chain (Oberdorster et al., 2004). The miners and workers exposed to the nanoparticles of quartz (the carcinogenic materials) are susceptible to the dangerous diseases. The researches show that the impacts of the carbon nanotubes are more toxic than the quartz dusts on mice's lungs in the laboratories (Lam et al., 2004). The high surface reactivity of quartz and carbon nanoparticles can make free radicals; consequently, it can cause the oxidation of the white blood cells and immune cells.

The formation of carbon nanotubes and nanocrystals are accumulated in the air.

Nanocrystals composed of the carbon particles are more dangerous than the individuals not the accumulated ones to the living organisms. The researches also show that the unprocessed carbon nanotubes, which are either displaced or aroused enough, can form the dust particles (Maynard et al., 2004). Carrying the carbon nanotubes is somehow hazardous to the health. Furthermore, the factories which are either the manufacturers or the consumers of the carbon nanotubes-based products endanger the health of workers (Oberdorster et al., 2004).

Increasing use of nanotechnology and nanomaterials has significantly increased exposure of workers to nanomaterials, increasing threats to employee health and to the environment (Savolainen et al., 2010). This necessitates the need for increased global research on the use of nanotechnology to combat unsanitary living conditions (Nowack and Bacheli, 2007).

The unclear adverse effects of nanotechnology on humans and the environment (Ostertag and Husing, 2008) have led many organizations in the world, such as the national institute of health, national nanotechnology initiative, nanomedicine roadmap initiative in the USA, center of nanotechnology, institute of nanotechnology, nanoscale science and nanotechnology group, manufactory engineering center, and other similar organizations in Europe to invest heavily in nanotechnology research.

This study is also done to promote research in the field of nanotechnology and nanoparticles as an emerging technology. Studies on the ecological effects of the chemicals often occur in the early stages of the materials consumption and their disposal. In addition to the ecological assessments in the consumption and disposal, we can do these studies in the stages of production of materials. In this case, the manufacturing processes and the ecological effects are less developed by the result. Many studies have been done about the assessment of the biological environment and health during the production process of a substance. In 2010a, Hasim and Hurmeh evaluated and compared the methyl methacrylate production based on the health indices through the six stages. In the same year (2010b), they introduce a method known as the health quotient index (HQI) in another study. The HQI method presents a simple 
approach to assess the people's health which some hazardous factors may expose their health; moreover, this method can present the ranking of the manufacturing process risks. Their method has been tested in six different- production process of the methyl methacrylate.

These authors also estimated the chemical concentration of fugitive emissions during chemical process design (Hassim, Perez and Hurme, 2010). Similar studies have been conducted by Srinivasan and Trong (2010). Gupta and Edward (2003) introduced some indices such as the Inherent Safety Design index. In another study, Rahman, Heikkila and Hurme (2005) compared inherent safety index methods and discussed their properties and limitations. A case study of methyl methacrylate process routes was conducted in 2005. In the same year, Faisal khan and Paul Amyotte presented the conceptual framework of the inherent safety index. Risza and Azmi (2010) proposed a methodology that integrated the hazard review technique with inherent safety, which is useful for identifying risks at an early stage of the production process

\section{Objectives}

This study aims to introduce a suitable method of zinc oxide nanostructure production with regard to health and environmental parameters.

In this study, spray pyrolysis and hydrothermal processes for producing nanostructured zinc oxide were compared under normal operating conditions with regard to health and environmental risks.

The high strength of zinc oxide under the harsh conditions of industrial processes and its high activity at the nanoscale (Rajendran et al., 2010) in comparison to the microscale (Zhang et al., 2009), low toxicity, good thermal stability, good oxidation resistibility, good biocompatibility, large specific surface area and high electron mobility (Pan and Huang, 2011) suggests the importance of using the material in different industries. The high consumption rate of zinc oxide in various industries on one hand, and the ability to produce zinc from domestic sources on the other hand, are encouraging factors for the study on health and environmental risks of producing nanostructured zinc oxide.

Spray pyrolysis is based on the liquid atomization technique (Madler, 2004). It is an economical, easy, and continuous technique (Charp et al., 2015). In the spray pyrolysis process, a solution of zinc salt $\left[\mathrm{Zn}\left(\mathrm{NO}_{3}\right)_{2} \cdot 6 \mathrm{H}_{2} \mathrm{O}\right]$ are placed under a pressure and temperature of 20 bar and $80{ }^{\circ} \mathrm{C}$, respectively. The decomposed droplet as resulting mixture was pumped as feedstock into a spray dryer reactor at a temperature of 500-800 ${ }^{\circ} \mathrm{C}$ (Ghaffarian et al., 2011). The product was subsequently fed into a cyclone to separate the particles based on their sizes. A scrubber and caustic soda were used to neutralize $\mathrm{NO}_{\mathrm{x}}$ emitted from filtering process.

The hydrothermal method is based on crystal synthesis at temperatures above $100^{\circ} \mathrm{C}$ and pressures above 1 atom (Hayesh and Hakuta, 2010). It uses simple equipment, is catalyst free and low cost (Aneesh, Vanaja and Javaraj, 2007), and constitutes a batch method. In this study the crystals of zincsalt $\left[\mathrm{Zn}\left(\mathrm{NO}_{3}\right)_{2} \cdot 6 \mathrm{H}_{2} \mathrm{O}\right]$ is used. Leached solution from reactor will be cold rapidly and then filtered.

In this study, we compared, for the first time, the spray pyrolysis and hydrothermal production processes of nanostructured zinc oxide under normal operating conditions in terms of health and environmental risks at Iran's Research Institute of Petroleum Industry (RIPI) in 2015. 
Environmental release and the exposure level to chemicals during each of the processes with the same production capacity was determined separately for each pollutant sources. Subsequently, spray pyrolysis and hydrothermal processes were compared pair-wisely using analytical hierarchy process based on respiratory harms, skin harms, and environmental damages such as air, water, and soil pollution to determine the optimal method in terms of health and environmental risks.

\section{Materials and methods}

As already mentioned this study aims to introduce a suitable method of zinc oxide nanostructure production with regard to health and environmental parameters. For this purpose, pollution sources in zinc oxide nanostructure spray pyrolysis and hydrothermal processes were identified. The Chemical Screening Tool for Exposure and Environmental Release (ChemSTEER) was used to model the release of possible pollutants and the amount of human exposure in each process.

ChemSTEER software, developed by the United States American Environmental Protection Agency (US EPA) was used to model the release of possible pollutants and the degree of human exposure in each process. The software is capable of estimating the extent of respiration and skin contact with chemicals during industrial and commercial production processes. It can also estimate the amount of chemicals released into the environment during industrial production (EPA, 2014).

According to the results of ChemSTEER, the spray pyrolysis and hydrothermal process were compared pairwise using the analytic hierarchy process (AHP) in Expert Choice based on five criteria. Respiratory and skin damage as the health subcriteria and air, water, and soil pollution as the environmental subcriteria to investigate suitable zinc oxide nanostructure production methods with regard to the environment and health. Criteria mentioned are the most important criteria in health (Hassim and Hurme, 2010c) and environmental assessment (Kweku et al., 2008; Som et al., 2011) which have frequently been used by researchers.

AHP method was performed by weighting of criteria and prioritizing of alternatives using eigenvector technique. This is one of the most comprehensive systems designed for decision making with multiple criteria by which it is possible to formulate the problem as a hierarchy. It also offers the possibility of involving qualitative and quantitative criteria in decision making (Saaty, 1986, 2008).

According to AHP results the box plot diagram of inverse risk has been drawn, and the optimal production process of nanostructured zinc oxide was introduced

\section{Results}

As mentioned earlier, each of the two processes has been studied from health and environmental aspects. For this, following the investigation of spray pyrolysis and hydrothermal processes and identification of pollution sources in each process, skin and respiratory exposure to chemicals released into the environment were modeled by ChemSTEER software.

The pollution sources of spray pyrolysis under normal operating conditions includes $\mathrm{NO}_{\mathrm{x}}$ fumes from the feeder, spray dryer, and scrubber and sodium nitrate solid waste from filtration. Pollution sources of hydrothermal process under normal operating 
conditions include NOx fumes from the reactor and waste water include sodium nitrate and different kind of solvent.

In this study, the emission sources and human exposure of spray pyrolysis and hydrothermal methods used in two semi-scale nanostructured zinc oxide production processes with a capacity of $2000 \mathrm{~kg} /$ year were modeled by ChemSTEER software. To run this software, the chemical properties of primary substances, including their vapor pressure, molecular weight, density, and solubility in water, were required. Next, operation parameters and polluting sources or activities were determined. ChemSTEER has provided default models. The estimation of the environmental release and chemical exposure occurs according to the operation process and polluting sources. Spray pyrolysis is a continuous process; hydrothermal is a batch process. The duration is eight hours for the former and one hour for the latter. Production per process of each is $100 \mathrm{~kg}$; the number of individuals exposed to the emissions in each working shift is 5 people.

According to the results, the average daily exposure resulting from respiratory contact with $\mathrm{NO}_{\mathrm{x}}$ emitted from the feeder, spray dryer, and scrubber in the spray pyrolysis process are $0.00012,0.00096$, and $0.00004 \mathrm{mg} / \mathrm{kg} / \mathrm{d}$, respectively. While the average daily exposures from inhalation and skin contact with the waste storage tank in the spray pyrolysis process containing sodium nitrate are 0.039 and $0.8088 \mathrm{mg} / \mathrm{kg} / \mathrm{d}$, respectively. The environmental release of $\mathrm{NO}_{\mathrm{x}}$ emitted from the feeder, spray dryer and scrubber in the spray pyrolysis process are $0.012,0.1,0.004 \mu \mathrm{g} / \mathrm{m}^{3}$, respectively. Moreover, the possible daily release rate of sodium nitrate from waste storage tank is $0.161 \mathrm{~kg} /$ day.

The average daily exposure resulting from respiratory contact with $\mathrm{NO}_{\mathrm{x}}$ emitted from the reactor in the hydrothermal process is $0.02 \mathrm{mg} / \mathrm{kg} / \mathrm{d}$. While the average daily exposures skin contact with the waste water in the hydrothermal process containing sodium nitrate and different kind of solvent is $1.2 \mathrm{mg} / \mathrm{kg} / \mathrm{d}$. The environmental release of NOx emitted from reactor in the hydrothermal process is $0.16 \mu \mathrm{g} / \mathrm{m}^{3}$.

Tables 1 and 2 present the results of respiratory and skin contact along with environmental release modeling for each of the pollution sources in spray pyrolysis and hydrothermal.

Table 1. Inhalation and skin contact

\begin{tabular}{|c|c|c|c|c|c|c|c|}
\hline \multirow{4}{*}{$\begin{array}{c}\text { Spray } \\
\text { Pyrolysis } \\
\text { Method }\end{array}$} & $\begin{array}{l}\text { Type of } \\
\text { Contact }\end{array}$ & $\begin{array}{c}\text { Pollution } \\
\text { Sources }\end{array}$ & $\begin{array}{c}\text { Potential } \\
\text { Dose } \\
\text { Rate } \\
(\mathrm{mg} / \mathrm{d})\end{array}$ & $\begin{array}{c}\text { Life } \\
\text { Time } \\
\text { Average } \\
\text { Daily } \\
\text { Dose } \\
(\mathrm{mg} / \mathrm{kg} / \mathrm{d})\end{array}$ & $\begin{array}{c}\text { Average } \\
\text { Daily } \\
\text { Dose } \\
\text { (mg/kg/d) }\end{array}$ & $\begin{array}{c}\text { Exposure } \\
\text { Limit } \\
\text { TWA } \\
(8 \text { h) }\end{array}$ & $\begin{array}{c}\text { Acute } \\
\text { Potential } \\
\text { Dose } \\
(\mathrm{mg} / \mathrm{kg} / \mathrm{d})\end{array}$ \\
\hline & \multirow{3}{*}{ Inhalation } & $\begin{array}{c}\mathrm{No}_{\mathrm{x}} \\
\text { emission } \\
\text { from } \\
\text { feeder } \\
\end{array}$ & 0.1546 & 0.000069 & 0.00012 & \multirow{3}{*}{$5 \mathrm{ppm}$} & 0.0022 \\
\hline & & $\begin{array}{c}\mathrm{No}_{\mathrm{x}} \\
\text { emission } \\
\text { from } \\
\text { spray } \\
\text { dryer }\end{array}$ & 1.2328 & 0.00055 & 0.00096 & & 0.018 \\
\hline & & $\begin{array}{c}\mathrm{No}_{\mathrm{x}} \\
\text { emission } \\
\text { from } \\
\text { scrubber }\end{array}$ & 0.061 & 0.000027 & 0.000048 & & 0.0009 \\
\hline
\end{tabular}




\begin{tabular}{c|c|c|c|c|c|c|c}
\hline & & $\begin{array}{c}\text { Waste } \\
\text { storage } \\
\text { (sodium } \\
\text { nitrate) }\end{array}$ & 49.99 & 0.022 & 0.039 & $\begin{array}{c}5 \mathrm{mg} / \mathrm{m}^{3} \\
\text { or } \\
1.438 \mathrm{ppm}\end{array}$ & 0.7142 \\
\cline { 2 - 8 } & Skin & $\begin{array}{c}\text { Waste } \\
\text { storage }\end{array}$ & 1033.23 & 0.4622 & 0.8088 & $\begin{array}{c}5 \mathrm{mg} / \mathrm{m}^{3} \\
\text { or } \\
1.438 \mathrm{ppm}\end{array}$ & 14.7604 \\
\hline \multirow{2}{*}{ Hydrothermal } & Inhalation & $\begin{array}{c}\mathrm{No}_{\mathrm{x}} \\
\text { emission }\end{array}$ & 4.98 & 0.0022 & 0.02 & $5 \mathrm{ppm}$ & 0.56 \\
\cline { 2 - 8 } & Skin & $\begin{array}{c}\text { Waste } \\
\text { water }\end{array}$ & 202.45 & 0.091 & 1.2 & - & 22.4 \\
\hline
\end{tabular}

Table 2. Environmental release

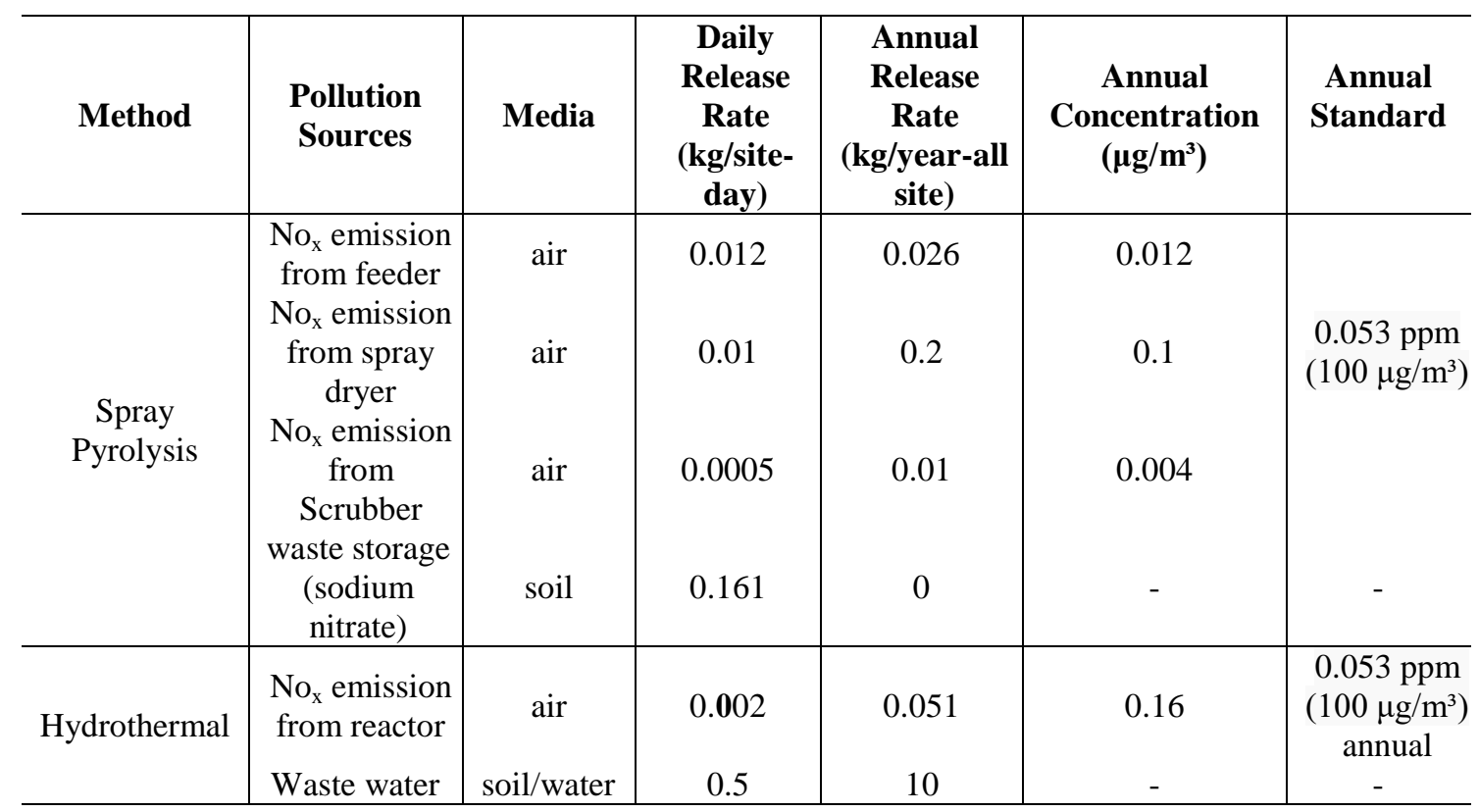

According to Table 1, the average daily exposure to $\mathrm{NO}_{\mathrm{x}}$ and solid particles in a sodium nitrate waste storage tank during spray pyrolysis and the average daily exposure to NOx from reactor during the hydrothermal process are below the 8-hour occupational exposure limit. Also, the average daily exposure of skin contact to sodium nitrate during spray pyrolysis is $0.8088 \mathrm{mg} / \mathrm{kg} / \mathrm{d}$, which is below the 8 -hour occupational exposure limit, regardless of the acute potential dose

According to Table 2, the emissions from feeder, spray dryer, scrubber during spray pyrolysis and reactor during hydrothermal process are below the standard.

To introduce a suitable method of zinc oxide nanostructure production with regard to health and environmental parameters, the spray pyrolysis and hydrothermal techniques were compared pair wisely using AHP in expert choice software based on respiratory harms, skin harms, air, water, and soil pollution according to the results of ChemSTEER. The criteria were weighted by averaging the scores in the structured questionnaires given by industrial and academic experts in environment, health, ecology, chemistry and nanotechnology.

The obtained results indicate that the hydrothermal process with $0.61 \mathrm{wt} \%$ has a lower health and environmental risk than the spray pyrolysis process with a 0.39 wt $\%$. 
Thus, it can be concluded that the hydrothermal process would be a more health and environment- friendly process for the production of nanostructured zinc oxide (Table 3).

Table 3. Pair wise comparison of spray pyrolysis and hydrothermal

\begin{tabular}{c|c|c|c|c|c|c}
\hline & \multicolumn{2}{|c|}{ Health criteria } & \multicolumn{2}{c|}{ Environmental criteria } & \multirow{2}{*}{ Final } \\
\cline { 2 - 6 } & $\begin{array}{c}\text { respiratory } \\
\text { harms }\end{array}$ & $\begin{array}{c}\text { skin } \\
\text { harms }\end{array}$ & $\begin{array}{c}\text { air } \\
\text { pollution }\end{array}$ & $\begin{array}{c}\text { soil } \\
\text { pollution }\end{array}$ & $\begin{array}{c}\text { water } \\
\text { pollution }\end{array}$ & result \\
\hline Spray pyrolysis & 0.125 & 0.5 & 0.25 & 0.5 & 0.5 & 0.39 \\
Hydrothermal & 0.875 & 0.5 & 0.75 & 0.5 & 0.5 & 0.61 \\
\hline
\end{tabular}

Also the box plot diagram of inverse risk has been drawn according to AHP results (Figure 1). Box plot diagram indicated that hydrothermal process leads to a higher health and environmental median inverse risk compared with spray pyrolysis. Obviously, higher inverse risk leads to a safer health and environmental condition. Thus it can be concluded that the hydrothermal process with higher inverse risk would be a more health- and environment-friendly process for the production of nanostructured zinc oxide.

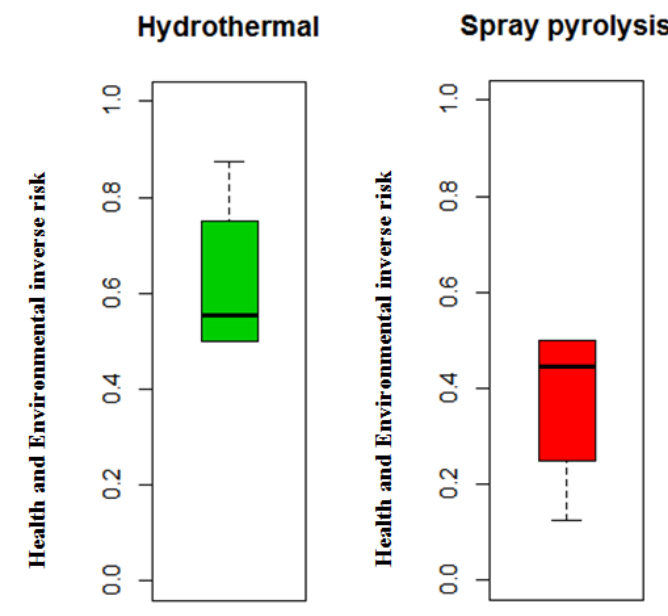

Figure 1. Box plot diagram of inverse risk

\section{Discussion}

Prior works have been carried out on the health and environmental impacts of nanotechnology (Gregory, 2010; Dreher, 2004; Moore, 2006; Steffi and Jurgen, 2007),

Studies on the ecological effects of the chemicals are often done in the early stages of material consumption and its disposal. In addition to the ecological assessments in the consumption and disposal, we need to study them in the production of materials. Thus, we can control the manufacturing processes and the ecological effects through the analysis of the results. several Studies on ecological and environmental risk assessment in production processes, especially during the early stages of the production process, except nano-materials, have also been conducted (Hassim and Hurme 2010a; Rahman et al., 2005; Srinivasan and Trong, 2008). 
What we can get from the similar surveys of the risk assessments of the chemicals in manufacturing processes is the lack of comprehensive studies on the nanomaterials production processes. Due to the growing development of the various methods of the nanomaterials and the development of the products based on nanoparticles, we need to apply the safer methods and to have the least ecological risks in the production of the nanomaterials. In this case, we are able to step in reducing the environmental risks associated with the development of this modern technology.

The above-mentioned results are based on health and environmental risk assessment of spray pyrolysis and hydrothermal synthesis of nanostructured zinc oxide on a semi-industrial scale. These findings could be helpful to mitigate ecological risk and scale up the existing pilot plant to an industrial unit with minimum environmental impacts.

The increasing use of nanoparticles as an attractive tool in the industry, as well as difficulties controlling the size and shape of nanomaterials, suggest the optimal method of nanomaterial production. This is despite the health and environmental consequences of nanomaterial production, which may be irreversible.

Studies on adverse health and environmental effects during the early stages of technology development and industrialization could effectively mitigate ecological risks. Process modification, substitution of hazardous chemicals with safer compounds, and presenting risk mitigation strategies are important topics, especially in nanomaterial production processes. These studies could be useful in identifying and reducing risks during the initial stages of the development process.

To this end, this study was conducted to identify the health and environmental risks of nanostructured zinc oxide production processes, which have received relatively little attention. The distinguishing feature of this study is to analyze the risks of nanomaterial production on a semi-industrial scale for the first time.

In this study the emission sources and human exposure of spray pyrolysis and hydrothermal methods used in two semi-scale nanostructured zinc oxide production processes were modeled by ChemSTEER software. Using ChemSTEER, spray pyrolysis, and hydrothermal techniques were compared pair-wise using AHP on respiratory harm, skin harms, air, water, and soil pollution indices.

According to the result the hydrothermal process with $0.61 \mathrm{wt} \%$ has a lower health and environmental risk than the spray pyrolysis process with a $0.39 \mathrm{wt} \%$, so the production of nanostructured zinc oxide by hydrothermal processes is less risky than spray pyrolysis from health and environmental viewpoints.

On the one hand there is the management of the environmental and ecological risks; on the other hand we need to take some necessary measures to improve the performance of the method in the early stages, because the development of the production processes could be much more efficient and cheaper.

It is therefore recommended that-to develop a safer industry and to prevent irreparable events and environmental impact-further research is required on this topic.

Evaluating the other processes in the production of nano-materials disposal, we can use either other models such as fuzzy models of high accuracy or the neural network models which are capable of making new structures for the information processing system. We can compare the results of the hierarchical models which are accessible, functional and reliable by them. It is clear that these studies could help both to develop more secure industries and to prevent the devastating effects of the ecological and environmental factors. 
Acknowledgement. This research was authorized by the Iran's Research Institute of Petroleum Industry (RIPI). The authors greatly acknowledge the support from Nanotechnology Research Center at RIPI.

\section{REFERENCES}

[1] Aneesh, P. M., Vanaja, K. A., Jayaraj, M. K. (2007): Synthesis of ZnO nanoparticles by hydrothermal method. - Journal of Nanophotonic Materials 6639: 1-9

[2] Charpe, S. D., Aghuwanshi, F. C., Lamdhade, G. T., Kalymwar, V. S. (2015): Synthesis of Nano structure Zinc Oxide by Spray Pyrolysis and its Characterizationfor Gas Sensing Application. - Journal of Electrical Engineering 3: 12-17

[3] Colvin, V. L. (2003): The potential environmental impact of engineered nanomaterials. Nature Biotechnol. 21:1166-70.

[4] Dreher, K. L. (2004): Health and Environmental Impact of Nanotechnology: Toxicological Assessment of Manufactured Nanoparticles - Journal of Toxicology Science 77: 3-5

[5] Drobne, D. (2007): Nanotoxicology for safe and nanotechnology. - Journal of Archives of Industrial Hygiene and Toxicology 58: 471-478

[6] Scrinis, G., Miller, G. (2006): Nanotechnology and the environment: Challenging the nano industry "green wash - Friend of the earth. - http://emergingtech.foe.org.au/

[7] Ghaffarian, H. R., Saiedi, M., Sayyadnejad, M. A., Rashidi, A. M. (2011): Synthesis of $\mathrm{ZnO}$ Nanoparticles by Spray Pyrolysis Method. - Iranian journal of chemistry and chemical engineering 30:1-6

[8] Gregory, M. (2010): The 5 principles of "Design for Safer Nanotechnology. - Journal of Cleaner production 18: 285-289

[9] Gupta, J. P., Edwards, D. W. (2003): A simple graphical method for measuring inherent safety. - Journal of hazardous materials 104: 15-30.

[10] Hassim, M. H, Hurme, M. (2010b): Inherent occupational health assessment during preliminary design stage. - Journal of Loss Prevention in the Process Industries 23: 476482

[11] Hassim, M. H, Hurme, M. (2010c): Inherent occupational health assessment during basic engineering stage. - Journal of Loss Prevention in the Process Industries 23: 260-268

[12] Hassim, M. H., Pérez, A. L., Hurme, M. (2010): Estimation of chemical concentration due to fugitive emissions during chemical process design. - Journal of Process Safety and Environmental Protection 88:173-184

[13] Hassim, M. H., Hurme, M. (2010a): Inherent occupational health assessment during process research and development stage. - Journal of Loss Prevention in the Process Industries 23: 127-138

[14] Hayashi, H., Hakuta, Y. (2010): Hydrothermal Synthesis of Metal Oxide Nanoparticles in Supercritical Water. - Journal of materials 3: 3794-3817

[15] ISO/IEC TR 13335-3:1998, Information technology - Guidelines for the management of IT Security -Part 3:Techniques for the management of IT Security

[16] Johnston, E. L., Mayer-Pinto, M., Crowe, T. P. (2015): Chemical contaminant effect on marine ecosystem functioning. - Journal of Applied ecology 52: 140-149

[17] Khan, F. I., Amyotte, P. R. (2005): A comprehensive quantitative tool for inherent safety and cost evaluation. - Journal of Loss Prevention in the Process Industries 18: 310-326

[18] Kweku Adu, I., Sugiyama, H., Fischer, U., Hungerbuhler, K. (2008): Comparison of methods for assessing environmental, health and safety (EHS) hazards in early phases of chemical process design. - Journal of Process Safety and Environmental Protection 86: 77-93

[19] Lam, C. W., James, J. T., McCluskey, R., Hunter, R. L. (2004): Pulmonary Toxicity of Single-Wall Carbon Nanotubes in Mice 7 and 90 Days after Intratracheal Instillation. Toxicol Sci. 77: 126-134 
[20] Madler, L. (2004): Liquid-fed aerosol reactors for one step synthesis of nano structured particle. - Journal of powder and particle 22: 107-120

[21] Maynard, A. D., Baron, P. A., Foley. M., Shvedova, A. A., Kisin, E. R., Castranova, V. (2004): Exposure to Carbon Nanotube Material: Aerosol Release During the Handling of Unrefined Single-Walled Carbon Nanotube Material. - Journal of Toxicology and Environmental Health-Part A, 67: 87-107

[22] Maynard, A. D. (2006): Nanotechnology: assessing the risks. - Nano Today 1: 22-33.

[23] McMahon, T. A., Halsted, N. T., Johnson, S., Raffel, T. R., Romansic, J. M., Crumrine, P. W., Rohr, J. R. (2012): Fungicide-induced declines of freshwater biodiversity modify ecosystem function and services. - Ecoligy Letter 15: 714-722

[24] Michener, W. K. (2006): Meta-information concepts for ecological data management. Journal of ecological information 1:3-7

[25] Moghimi, S. M., Hunter, A. C. (2001): Capture of Stealth Nanoparticles by the Body's Defenses Critical Reviews in Therapeutic Drug Carrier Systems 18: 527-550.

[26] Moore, M. N. (2006): Do nanoparticles present ecotoxicological risks for the health of the aquatic environment? - Journal of Environment International 32: 967-976

[27] Nowack, B., Bucheli, T. D. (2007): Occurrence, behavior and effects of nanoparticles in the environment. - Journal of Environmental Pollution 150: 5-22

[28] Oberdorster, G., Sharp, Z., Atudorei, V., Elder, A., Gelein, R., Kreyling, W., Cox, C. (2004): Translocation of Inhaled Ultrafine Particles to the Brain. - Inhalation Toxicology 16: $437-445$

[29] Ostertag, K., Husing, B. (2008): Identification of starting points for exposure assessment in the post-use phase of nanomaterial-containing products. - Journal of Cleaner production 16: 938-948

[30] Pan, A. W. L, Huang, W. (2011): Recent progress in the $\mathrm{ZnO}$ nanostructure-based sensors. - Journal of Materials Science and Engineering B 176: 1409-1412

[31] Poirier, M. C. (2004): Chemical-Induced DNA Damage and Human Cancer Risk. - Nat. Rev. Cancer. 4: 630-637

[32] Rahman, M., Heikkila, A. M., Hurme, M. (2005): Comparison of inherent safety indices in process concept evaluation. - Journal of Loss Prevention in the Process Industries 18: 327-334

[33] Rajendran, R., Balakumar, C., Hasabo, A. M. A., Jayakumar, S., Vaideki, K., Rajesh, E. M. (2010): Use of zinc oxide nano particles for production of antimicrobial textiles. Eng. Sci. Technol. 2: 202-208

[34] Rickerbya, D. G., Morrison, M. (2007): Nanotechnology and the environment: A European perspective. - Journal of Science and Technology of Advance Materials 8: 1924

[35] Risza, R., Azmi, M. S. (2010): Qualitative assessment for inherently safer design (QAISD) at preliminary design stage. - Journal of loss prevention in the process industries 23: 157-165

[36] Saaty, T. L. (2008): Decision making with the analytic hierarchy process. - International Journal of Services Sciences 1: 83-98

[37] Saaty, T. L. (1986): Axiomatic Foundation of the Analytic Hierarchy Process. - Journal of Manage Science 32: 841-855

[38] Savolainen, K., Alenius, H., Norppa, H., Pylkkänen, L., Tuomi, T., Kasper, G. (2010): Risk assessment of engineered nanomaterials and nanotechnologies-A review. - Journal of Toxicology 269: 92-104

[39] Som, C., Wick, P., Krug, H., Nowack, B. (2011): Environmental and health effects of nanomaterials in nanotextiles and façade coatings. - Journal of Environmental International 37: 1131-1142

[40] Srinivasan, R., Trong Nhan, N. (2008): A statistical approach for evaluating inherent benign-ness of chemical process routes in early design stages. - Journal of Process Safety and Environmental Protection 86:163-174 
[41] Steffi, F., Jurgen, S. (2007): Environmental, health and safety aspects of nanotechnology implications for the R\&D in (small) companies. - Journal of Science and Technology of Advance Materials 8: 12-18

[42] US Environmental Protection Agency (2014): Available from: http://www.epa.gov/tscascreening-tools/chemsteer-chemical-screening-tool-exposures-and-environmentalreleases

[43] Vall-llosera, M., Sol, D. (2009): A global risk assessment for the success of bird introductions. - Journal of Applied Ecology 46: 787-795

[44] Zhang, L., Jiang, Y., Ding, Y., Daskalakis, N., Jeuken, L., Povey, M., York, D. W. (2009): Mechanistic investigation into antibacterial behavior of suspensions of $\mathrm{ZnO}$ nanoparticles against E.coli. - J. Nanopart. Res. 12: 1625-1636 